\title{
Fødselsvekt og selvmord: er det noen sammenheng?
}

\author{
Berit Grøholt \\ Psykiatrisk institutt, Universitetet i Oslo; Senter for psykisk helse barn og ungdom, Ullevål Universitetssykehus \\ Korrespondanse: Berit Grøholt, Senter for psykisk helse Sogn, Forskningsenheten, Boks 26, Vinderen, 0319 Oslo \\ Telefon: 23492326 Telefaks 23492302 e-post: berit.groholt@medisin.uio.no
}

\begin{abstract}
SAMMENDRAG
Siden Salk i 1985 introduserte ideen om at fødselskomplikasjoner kunne øke risikoen for tenåringsselvmord, har flere studier tatt opp problemstillingen, men med motstridende funn. Sammenhengen mellom lav fødselsvekt og forhøyet mortalitet er vist i en rekke studier, og i noen tilfelle også for selvmord. Artikkelen gjennomgår relevant litteratur, og mye taler for at det er en sammenheng mellom intrauterine komplikasjoner og selvmord. I artikkelen drøftes funn og mulige mediatorer: Endret programmering og utvikling av CNS intrauterint kan føre til dårlig mental helse, kognitiv dysfunksjon og dårlig stresstoleranse. Om lav sosial klasse, dårlig psykisk helse hos foreldre, føstegangsfødende ung mor er konfoundere (effektforvekslere) eller en del av årsakskjeden er ennå ikke klarlagt.
\end{abstract}

Grøholt B. Suicide and low birth weight: are they associated? Nor J Epidemiol 2005; 15 (1): 25-28.

\section{ENGLISH SUMMARY}

The paper quotes and discusses studies addressing the association between suicide and low birth weight. The results are partly contradictory, but still there seems to be a connection between suicide and low birth weight/birth length. This connection may be mediated through reduced mental health, low stress tolerance or cognitive deficits, all factors that are possibly related to the development of the CNS in utero. To which extent low socioeconomic status, low mental health in parents, low maternal age and nulliparity are factors in the causal pathway or confounders are not yet clarified.

\section{TIDLIGE STUDIER}

I 1985 publiserte Salk (1) en artikkel der han beskrev økt forekomst av obstretiske komplikasjoner hos tenåringer som senere døde ved selvmord. Hans hypotese var at komplikasjoner under svangerskap og fødsel gjorde barn mer sårbare for negative faktorer $\mathrm{i}$ omgivelsene. Tre forhold rundt fødselen hadde en signifikant sammenheng med senere selvmord: pustebesvær som varte utover en time ved fødsel, ingen antenatal omsorg før 20. svangerskapsuke og kronisk lidelse hos moren.

Barker (2) fulgte opp dette i 1995 ved å se på fødselsvekt og vektøkning første leveår hos 43 som døde av selvmord i en kohort på 10141 personer i England. Han fant normal fødselsvekt, men redusert vektøkning i første leveår, sammenliknet med resten av kohorten etter at han kontrollerte for sosial klasse og om barna ble ammet. Han mente videre at det ikke fantes indikasjoner på at barna ble utsatt for dårlig omsorg første leveår. Selv om det ikke var funnet lav fødselsvekt blant de som døde ved selvmord var Barkers hypotese at årsaken til den dårlige vektøkningen var knyttet til endringer i endokrine forhold. Han mente dårlig ernæring eller andre intrauterine forhold førte til avvikende programmering av hypotalamus-hypofyse-binyrebarkaksen (HPA-aksen) eller hypotalamus-tyroidea-aksen in utero.

\section{Kritikk}

Hollis kritiserte Barkers resonnementer etter studien i 1995 (3). Han hevdet for det første at avvik in utero med effekt på endokrine forhold også skulle gi avvik i fødselsvekt. Videre etterlyste han informasjon om depresjon post partum hos moren. Post partum depresjoner kunne være en god forklaring på lav vektøkning første leveår, det vil si manglende trivsel hos barnet (relative failure to thrive). Flere arbeider hadde dokumentert en slik effekt $(4,5)$.

\section{SENERE STUdIER}

Imidlertid er det holdepunkter for at problemer $\mathrm{i}$ fosterlivet påvirket HPA-aksen. Det er kjent at en senvirkning kan være endret stemningsleie senere i livet (6). I tråd med dette fant Barkers gruppe (7) at menn med lav fødselsvekt hadde en økt risiko for senere depresjon, også etter at en kontrollerte for sosial klasse ved fødsel og ved undersøkelsestidspunktet. Videre ble det kontrollert for aktuelle sorgreaksjoner, fysiske sykdommer og sosial isolasjon. Man fant ingen slik sammenheng for kvinner. I en senere og større studie fant Gale og Martyn det motsatte; en sammenheng for kvinner men ikke for menn (8).

Også Brown (9) gjorde liknende funn. Han fant at menn født etter en vinter med uttalt sult i Nederland 
under 2. verdenskrig hadde økt risiko for depresjon i voksen alder.

I 1998 forsøkte Neugebauer å replikere Barkers funn (10). Han laget en indeks av komplikasjoner hos mor eller barn prenatalt og perinatalt, og fant ingen forskjell mellom 189 personer 15-22 år døde av selvmord, og et matchet kontrollmateriale på 378 personer.

I 2003 undersøkte Li (11) sammenhengen mellom barnemortalitet og fødselsvekt. Han undersøkte 6247 dødsfall blant unge under 20 år. Selv om han fant en klar økt dødelighet, var det ingen økning av dødsfall pga. selvmord.

Også Andersen og Osler (12) fant en økt mortalitet knyttet til lav fødselsvekt og -lengde. Sterkest var sammenhengen når moren var 35 år gammel og eldre. Ponderal indeks som kan sees som et uttrykk for vekst in utero, viste ingen sammenheng med mortalitet. De viste også at lav sosial klasse var assosiert med høy mortalitet, og at både sosial klasse og barnets størrelse ved fødsel hadde en selvstendig effekt. I en senere studie fant de ingen sammenheng mellom lav fødselsvekt og depresjon (13). De fant ikke noen spesiell sammenheng når det gjaldt selvmord i noen av analysene.

Til tross for at Barker mente at hans studie støttet Salks funn fra 1985, hadde i realiteten ingen funnet en statistisk sammenheng mellom selvmord og fødselsvekt. I 2004 publiserte imidlertid Mittendorfer-Rutz og medarbeidere i Sverige en studie som viste en slik sammenheng mellom fødselsvekt og selvmord (14). De fant 29 selvmord blant 21306 personer med en fødselsvekt under $2500 \mathrm{~g}$. Dette var flere enn forventet, og ga en hazard ratio på 2,23 $(95 \% \mathrm{CI}=1,43-3,46)$. De fant også høyere selvmordshyppighet dersom morens alder var under 20 år $(\mathrm{HR}=2,30,95 \% \mathrm{CI}=1,4-3,22)$. I analysene kontrollerte de for kjønn, grad av prematuritet, morens utdanning og antall tidligere fødsler.

De svenske forskerne hadde også et mål for selvmordsforsøk som førte til innleggelse i sykehus. Også personer innlagt etter selvmordsforsøk var mindre ved fødsel. I denne multivariate analysen valgte forskerne å anvende fødselslengde og ikke fødselsvekt som mål. De som ble innlagt var kortere ved fødsel $(39-47 \mathrm{~cm}$ ga en hazard ratio på 1,29 , mens $48-49 \mathrm{~cm}$ ga en ratio på 1,06, begge statistisk signifikante). Også andre risikofaktorer var signifikante: Hadde moren tre eller flere tidligere fødsler økte risikoen for selvmordsforsøk, i likhet med lav utdanning og ung alder hos moren. Barn av mødre over 29 år hadde en signifikant redusert risiko for selvmordsforsøk.

Denne studien er stor og representativ, og tyder på at det er en sammenheng mellom intrauterin vekst og senere selvmord. Norske registerdata gjør det mulig å se på evt. sammenheng mellom fødselsvekt, fødselskomplikasjoner (medisinsk fødselsregister) og selvmord (dødsårsaksregisteret), og en slik studie er satt $i$ gang. Denne studien kan eventuelt styrke eller svekke funnene fra den svenske studien.

\section{MUlige MEKANiSMER}

Ingen av disse studiene kan si noe om hva som er mulige mekanismer bak slik sammenheng, og avvikende forhold $\mathrm{i}$ fosterlivet kan øke senere sårbarhet via flere mekanismer.

\section{Psykiske lidelser}

En rekke studier har vist sammenheng mellom lav fødselsvekt og senere psykisk lidelse. Best er dette dokumentert for schizofreni som nå oppfattes av mange som en neuropsykiatrisk utviklingsforstyrrelse $(15,16)$, men også økt forekomst av depresjon er beskrevet $(7,8)$. Både schizofreni og depresjon er viktige risikofaktorer for selvmord. Det er også holdepunkter for at lav fødselsvekt har en selvstendig sammenheng med ADHD (Attention Deficit Hyperactivity Disorder) (17) selv etter at en har kontrollert for risikofaktorer som sosial klasse, røyking, alkoholbruk, ADHD og utagerende atferd blant nære familiemedlemmer.

\section{Kognitive avvik}

Redusert kognitiv funksjon er også beskrevet som en senfølge av lav fødselsvekt $(18,19)$. Avvikene synes å normaliseres med økende alder, og Martyn fant ingen sammenheng mellom fødselsvekt og IQ hos voksne (20). Han fant en svak sammenheng mellom hodeomkrets ved fødsel og IQ. Sammenhengen mellom kognitive problemer og selvmordsatferd er påvist i en rekke arbeider. Blant annet fant Dieserud en sammenheng mellom redusert problemløsningsevne kombinert med depressive følelser og økt risiko for selvmordsatferd i en norsk studie (21).

\section{Stress}

Stress i tidlige leveår og trolig også intrauterint kan føre til hypersensitivitet i HPA-aksen. En følge av dette er at stress tåles dårligere (6). Denne teorien styrkes av en svensk studie som viste at gutter med dårlig vekst intrauterint hadde økt sårbarhet $\mathrm{i}$ forhold til stress da de ble testet i forbindelse med militæret (22). Avvik i HPA-aksen er relatert til suicidal atferd. Selv om resultatene av studiene ikke er helt entydige, synes økt aktivitet i HPA-aksen å disponere for suicidal atferd.

\section{Mors alder og paritet}

Også lav alder hos mor er relatert til lav fødselsvekt (14), og til senere psykiske vansker hos barna. Mulige mekanismer er dårlig ernæring intrauterint eller redusert omsorg etter fødsel. Vi vet og at tidlig svangerskap er knyttet til en rekke andre risikofaktorer som kan føre til lav fødselsvekt; røyking, bruk av alkohol. Førstefødte har uavhengig av øvrige risikofaktorer redusert fødselsvekt (23). Lewinsohn har tidligere vist 
at barn født av tenåringsmødre har en økt risiko for å gjenta et selvmordsforsøk (24).

\section{Fodselskomplikasjoner}

Salk la stor vekt på komplikasjoner rundt fødselen i sin studie fra 1985. I den svenske studien (14) ble en rekke komplikasjoner i svangerskap og ved fødsel registrert uten at en fant noen sammenheng med senere selvmord. Heller ikke Neugebauer (10) fant noen sammenheng.

\section{Sosial klasse}

Det er en sammenheng mellom lav sosioøkonomisk status og de fleste av mekanismene nevnt over. Det gjelder psykiatrisk sykelighet, kognitive problemer, stress, dårlig ernæring og lav alder ved første fødsel. De fleste av studiene hevder å ha kontrollert for sosial klasse, men målene som er brukt varierer og er neppe fullstendige. Den svenske studien brukte antall års utdanning hos mor som indikator.

Underernæring in utero kan føre til endringer i utviklingen av sentralnervesystemet, med endret psykisk helse, slik det er vist i flere studier (25). Dårlige sosioøkonomiske forhold kan knyttes til dårlig ernæring $\mathrm{i}$ fosterlivet. Et viktig poeng er at morens psykiske helse ikke er rapportert i noen av studiene. Det er mulig at dårlig psykisk helse hos moren i svangerskapet kan føre til både lavere fødselsvekt og øke risikoen for selvmord. Effekten kan medieres både via under- eller feilernæring, via dårligere omsorg eller via genetisk sårbarhet.

\section{KONKLUSJON}

Selv om studiene dels gir motstridende resultater trekker funnene i retning av at det er en sammenheng mellom lav fødselsvekt og senere selvmord. Mekanismen er trolig sammensatt og effekten kan medieres via dårlig psykisk helse, lavere stresstoleranse eller dårligere kognitive forhold. Dårlig ernæring av fosteret kan føre til programmeringsfeil som påvirker disse funksjonene. Det er uklart hvilke roller lav sosioøkonomisk status, dårlig psykisk helse hos foreldre, paritet eller ung alder hos moren, spiller.

Arbeidet for å forebygge selvmord er høyt prioritert i Norge. Hvorvidt en økning av den gjennomsnittlige fødselsvekt kunne forebygge selvmord, er høyst usikkert. Avklaring av fødselsvektens betydning gjennom videre forskning er derfor viktig.

\section{REFERANSER}

1. Salk L, Lipsitt LP, Sturner WQ, Reilly BM, Levat RH. Relationship of maternal and perinatal conditions to eventual adolescent suicide. Lancet 1985; 1: 624-627.

2. Barker DJP, Osmond C, Rodin I, Fall CHD, Winter PD. Low weight gain in infancy and suicide in adult life. BMJ 1995; 311: 1203.

3. Hollis C. Low weight gain in infancy and suicide in adult life. BMJ 1996; 312: 510.

4. Duniz M, Scheer PJ, Trojovsky A, Kaschnitz W, Kvas E, Macari S. Changes in psychopathology of parents of NOFT (non-organic failure to thrive) infants during treatment. Eur Child Adolesc Psychiatry 1996; 5: 93-100.

5. Murray L. The impact of postnatal depression on infant development. J Child Psychol Psychiatry 1992; 33: 543-561.

6. Teicher MH, Andersen SL, Polcari A, Anderson CM, Navalta CP, Kim DM. The neurobiological consequences of early stress and childhood maltreatment. Neurosci Biobehav Rev 2003; 27: 33-44.

7. Thompson C, Syddall H, Rodin I, Osmond C, Barker DJP. Birth weight and the risk of depressive disorder in late life. Br J Psychiatry 2001; 179: 450.

8. Gale CR, Martyn CN. Birth weight and later risk of depression in a national birth cohort. Br J Psychiatry 2004; 184: 28-33.

9. Brown AS, Susser ES, Lin SP, Neugebauer R, Gorman JM. Increased risk of affective disorders in males after second trimester prenatal exposure to the Dutch hunger winter of 1944-45. Br J Psychiatry 1995; 166: 601606.

10. Neugebauer R, Reuss ML. Association of maternal, antenatal and perinatal complications with suicide in adolescence and young adulthood. Acta Psychiatr Scand 1998; 97: 412-418.

11. Li CI, Daling JR, Emanuel I. Birthweight and risk of overall and cause-specific childhood mortality. Paediatr Perinat Epidemiol 2003; 17: 164-170.

12. Andersen AM, Osler M. Birth dimensions, parental mortality, and mortality in early adult age: a cohort study of Danish men born in 1953. Int J Epidemiol 2004; 33: 92-99.

13. Osler M, Andersen AM, Due P, Lund R, Damsgaard MT, Holstein BE. Socioeconomic position in early life, birth weight, childhood cognitive function, and adult mortality. A longitudinal study of Danish men born in 1953. J Epidemiol Community Health 2003; 57: 681-686. 
14. Mittendorfer-Rutz E, Rasmussen F, Wasserman D. Restricted fetal growth and adverse maternal psychosocial and socioeconomic conditions as risk factors for suicidal behaviour of offspring: a cohort study. Lancet 2004; 364: 1135-1140.

15. Maki P, Veijola J, Jones PB, Murray GK, Koponen H, Tienari P, Miettunen J, Tanskanen P, Wahlberg KE, Koskinen J, Lauronen E, Isohanni M. Predictors of schizophrenia - a review. Br Med Bull 2005; 73: 1-15.

16. Jones PB, Rantakallio P, Hartikainen AL, Isohanni M, Sipila P. Schizophrenia as a long-term outcome of pregnancy, delivery, and perinatal complications: a 28-year follow-up of the 1966 north Finland general population birth cohort. Am J Psychiatry 1998; 155: 355-364.

17. Mick E, Biederman J, Prince J, Fischer MJ, Faraone SV. Impact of low birth weight on attention-deficit hyperactivity disorder. J Dev Behav Pediatr 2002; 23: 16-22.

18. Shenkin SD, Starr JM, Pattie A, Rush MA, Whalley LJ, Deary IJ. Birth weight and cognitive function at age 11 years: the Scottish Mental Survey 1932. Arch Dis Child 2001; 85: 189-196.

19. Shenkin SD, Starr JM, Deary IJ. Birth weight and cognitive ability in childhood: a systematic review. Psychol Bull 2004; 130: 989-1013.

20. Martyn CN, Gale CR, Sayer AA, Fall C. Growth in utero and cognitive function in adult life: follow up study of people born between 1920 and 1943. BMJ 1996; 312: 1393-1396.

21. Dieserud G, Roysamb E, Ekeberg O, Kraft P. Toward an integrative model of suicide attempt: a cognitive psychological approach. Suicide Life Threat Behav 2001; 31: 153-168.

22. Nilsson PM, Nyberg P, Ostergren PO. Increased susceptibility to stress at a psychological assessment of stress tolerance is associated with impaired fetal growth. Int J Epidemiol 2001; 30: 75-80.

23. Melve KK, Skjaerven R, Oyen N. Families with a perinatal death: is there an association between the loss and the birthweight of surviving siblings? Paediatr Perinat Epidemiol 2002; 16: 23-32.

24. Lewinsohn PM, Rohde P, Seeley JR. Psychosocial risk factors for future adolescent suicide attempts. $J$ Consult Clin Psychol 1994; 62: 297-305.

25. Neugebauer R, Hoek HW, Susser E. Prenatal exposure to wartime famine and development of antisocial personality disorder in early adulthood. JAMA 1999; 282: 455-462. 